\title{
Triterpenoid $a$-amyrin stimulates proliferation of human keratinocytes but does not protect them against UVB damage
}

\author{
Edyta Biskup ${ }^{1,3}$, Marek Gołębiowski², Robert Gniadecki³ ${ }^{3}$ Piotr Stepnowski² \\ and Ewa Łojkowska ${ }^{1}$
}

'Department of Dermatology, Bispebjerg Hospital, Copenhagen, Denmark; 2Department of Environmental Analysis, Faculty of Chemistry, University of Gdansk, Gdansk, Poland; ${ }^{3}$ Department of Plant Protection and Biotechnology, Intercollegiate Faculty of Biotechnology, University of Gdansk and Medical University of Gdansk, Gdansk, Poland

\begin{abstract}
Rhaponticum carthamoides plants ("maral root") are widely used in Siberian folk medicine. The present study reports for the first time the presence of pentacyclic terpenoid, $a$-amyrin, in methanol extract from leaves of this plant. $a$-Amyrin induced proliferation of human keratinocytes (HaCaT) by about $18 \%$ while other extract components were ineffective. A panel of biochemical and cellbased assays testing the antioxidative and cytoprotective activites of $a$-amyrin indicated no antioxidative activity of this compound. a-Amyrin did not protect $\mathrm{HaCaT}$ cells against the damage caused by UVB radiation.
\end{abstract}

Key words: a-amyrin, Rhaponticum carthamoides, BrdU incorporation, antioxidant activity, UVB

Received: 17 October, 2011; revised: 01 March, 2012; accepted: 04 April, 2012; available on-line: 11 May, 2012

\section{INTRODUCTION}

Plants are a rich source of biologically active compounds used in the cosmetic and pharmaceutical industry. Introducing a plant-based product to the market, however, has to be preceded by a thorough analysis of its activity and potential toxicity. The traditional use of a specific plant often suggests the direction of research. The starting point is usually the screening of activities of a crude plant extract, followed by the identification of active constituents.

Many plant-derived compounds modulate cell proliferation, acting as cytotoxic agents (i.e., potential antineoplastic drugs) or by stimulating cell growth (i.e., potential application in wound healing). Herbal remedies have long been reported as biologically active agents promoting wound healing and used for treatment of skin disorders. Their ability to stimulate cell proliferation (Brunold et al., 2004), differentiation of keratinocytes (Lee et al., 2007), collagen synthesis (Aslam et al., 2006) and to alleviate psoriasis symptoms (Reuter et al., 2010) has been described.

Another interesting aspect is the antioxidative potential of plant-derived preparations and compounds. Reactive oxygen species (ROS) play a role in physiological processes such as cell signalling (Thannical and Fanburg, 2000 ) or in the microbicidal activity of phagocytes (Babior 1984). However, if present in excess, ROS may cause cell damage by reacting with nucleic acids, membrane lipids and proteins (Muller \& Gurster, 1993; Leeuwenburgh et al., 1998), and in the longer run might be associated with initiation or promotion of diseases like cancer or atherosclerosis (Kehrer 1993). Hence, plant- originated antioxidants may be valuable as potential cytoprotective agents.

Rhaponticum carthamoides (Willd) Iljin, a perennial plant belonging to the Compositae (Asteraceae) family, has been widely used in Siberian folk medicine, mostly to treat overstrain and common weakness after illnesses. Recently it gained attention as a rich source of ecdysteroids, compounds with potentially adaptogenic and anabolic activity (reviewed by Yance, 2004). In addition to ecdysteroids, several other biologically active compounds have been isolated from $R$. carthamoides, including flavonoid glycosides, polyphenolic acids (Sharaf et al., 2001; Miliauskas et al., 2005), $N$-feruloserotonin isomers (Pavlik et al., 2002) and thiophene polyacetylenes (Chobot et al., 2003). A number of preparations based on $R$. carthamoides-derived compounds, mainly designed for sportsmen, are commercially available. An R. carthamoides plantation has recently been established in Lubiewice, Poland by FITOSTAR $^{\circledR}$ (Biskup et al., 2007).

Since $R$. carthamoides is highly interesting from the pharmacognostic point of view, we analyzed biological activities of crude $R$. carthamoides extracts, extract fractions and pure compounds present in $R$. carthamoides leaf tissue (Biskup \& Lojkowska, 2009). The present study documents for the first time the presence of a triterpenoid $a$-amyrin in $R$. carthamoides leaf tissue extract.

a-Amyrin is a pentacyclic terpenoid synthetized by a number of plants, i.a. Callicarpa acuminata H. B. K. (Verbenaceae) from Mexico, Protium heptaphyllum (Burseraceae) from the Amazon, Carmona retusa (Boraginaceae) found in Philippines, and many more (Anaya et al., 2003; Villaseñor et al., 2004; Oliveira et al., 2005). This compound is usually found in plant extracts together with its isomer $\beta$-amyrin, differing in the placement of one methylene group (C-19 and C-20, respectively).

It has been demonstrated that a mixture of both isomers produces pronounced antinociception in the capsaicin test (decreased face rubbing behavior in rats), (Holanda Pinto et al., 2008). The analgesic effect was observed only in the case of second phase reaction, corresponding to inflammatory pain rather then to acute neurogenic pain (Holanda Pinto et al., 2008). On the other hand, the anti-inflammatory activity of these compounds

e-mail: edyta.biskup@gmail.com

Abbreviations: BrdU, bromodeoxyuridine; $c-\mathrm{H}_{2} D C F-D A$, carboxy$-2,7^{\prime}$-dichlorodihydrofluorescein diacetate; CPDs, cyclopyrimidine dimmers; DMEM, Dulbecco's Minimal Essential Medium; DPPH, diphenyl 1-picrylhydrazyl free radical; FCS, fetal calf serum; FRAP, ferric reducing antioxidant power; GC-MS, gas chromatography-mass spectrometry; ROS, reactive oxygen species. 
measured in carrageenan-induced mouse paw edema test seemed to be very low (Villaseñor et al., 2004). A mixture of $a$ - and $\beta$-amyrin isomers protects liver against acetaminophen-induced injuries (Oliveira et al., 2005) and ameliorates L-arginine-induced acute pancreatitis (Melo et al., 2010). a-Amyrin esters were also reported to exhibit significant biological activity, namely cytotoxic (Barros et al., 2011) and anti-inflammatory (Akihisa et al., 2010).

Having confirmed the presence of a-amyrin in R. carthamoides leaf tissue, we focused on analyzing its biological activities.

\section{MATERIALS AND METHODS}

Plant material and extraction procedure. Raponticum carthamoides leaves were obtained from the FITO$\mathrm{STAR}^{\circledR}$ plantation in Lubiewice (Kujawsko-pomorskie vojvodship), Poland. Voucher specimens are deposited at the Intercollegiate Faculty of Biotechnology, UG and MUG. Plant secondary metabolites were extracted by 30 -min. sonication (PolSonic) in methanol (1g dry leaves powder in $20 \mathrm{ml}$ ). Plant residue was removed by filtration through double Whatman filter paper (no. 1) and methanol was evaporated, using a vacuum rotary evaporator. Extract was weighed and dissolved in methanol again (4 ml).

Detection of amyrin by gas chromatography combined with mass spectrometry (GS-MS). Samples were dried under nitrogen and silylized with $100 \mu \mathrm{l}$ of a mixture of bis(trimethylsilyl)acetamide and chlorotrimethylsilane (99:1; Sigma Aldrich) for $24 \mathrm{~h}$ at $25^{\circ} \mathrm{C}$. The analyses were carried out on a Clarus 500 (Perkin Elmer) gas chromatograph equipped with a split ratio of $1: 30$ for the injection port and direct connection to a FID. An RTX 5 column $(30 \mathrm{~m} \times 0.25 \mathrm{~mm}$ i.d., film thickness $0.1 \mu \mathrm{m})$ was used. The carrier gas was argon. For reliable analysis, the injector and detector temperatures were $310^{\circ} \mathrm{C}$. The following temperature program was applied: $100-310^{\circ} \mathrm{C}$, rate $4^{\circ} \mathrm{C} / \mathrm{min}$. Mass spectra $(70 \mathrm{eV})$ were recorded on a SSQ 710 mass spectrometer (Finnigan). The samples were introduced through a Hewlett-Packard 5890 gas chromatograph equipped with the same columns and under the same chromatographic conditions as for the GC analysis but with helium as carrier gas. The ion source was maintained at $220^{\circ} \mathrm{C}$. The identification $a$-amyrin was based on the mass spectrum and retention time.

Cell culture conditions. HaCaT cells (spontaneously immortalized human keratinocytes, originally provided by Dr. M.R. Pittelkow; Mayo Clinic, Rochester, MI, USA. were grown in DMEM GlutaMAX (Gibco) medium, supplemented with 10\% fetal calf serum (FCS; Gibco). After reaching about $70-80 \%$ confluence cells were harvested by trypsinization and seeded at a density $10^{5}$ cells per flask. The medium was exchanged twice a week.

Methylene blue assay (Faurschou et al., 2008). Cells were seeded in 24-well plates at $10^{5}$ cells/well and let to attach overnight. a-amyrin (Sigma), dissolved in 2-propanol, was added to the final concentration of 10,20 or $40 \mu \mathrm{g} / \mathrm{ml}$ and cells were incubated for 24 or $48 \mathrm{~h}$. Final 2 -propanol concentration was $0.8 \% \mathrm{v} / \mathrm{v}$ in all assays, and it did not affect cell viability. After time periods indicated cells were fixed in $0.4 \%$ formaldehyde and stained with methylene blue (Merck) for $20 \mathrm{~min}$. Cells were then washed with distilled water and lysed in $0.1 \mathrm{M} \mathrm{HCl}$ and relative protein content was determined spectrophotometrically at the $595 \mathrm{~nm}$.
Clonogenic assay (Faurschou et al., 2008, modified). Cells were seeded in 6-cm diameter Petri dishes at a density of 200 cells/dish and let to attach overnight. $\alpha$-Amyrin (Sigma), dissolved in 2-propanol, was added to the final concentration of 5,10 or $20 \mu \mathrm{g} / \mathrm{ml}$ and cells were incubated for 10 days. After time periods indicated cells were fixed in $0.4 \%$ formaldehyde and stained with methylene blue (Merck) for $20 \mathrm{~min}$. Cells were then washed with distilled water and colonies were counted.

Bromodeoxyuridine (BrdU) incorporation assay. Cells were seeded in 6 -well plates at $4 \times 10^{5}$ cells/ well and let to attach overnight. After $24 \mathrm{~h}$ of incubation with a-amyrin $(10,20,40 \mu \mathrm{g} / \mathrm{ml})$ cells were pulsed for $20 \mathrm{~min}$ with $10 \mu \mathrm{M}$ BrdU and fixed in ice-cold $70 \%$ ethanol for at least $20 \mathrm{hr}$. Then, cells were washed with PBS, incubated in $2 \mathrm{M} \mathrm{HCl}$ for $30 \mathrm{~min}$, washed in neutralizing buffer $\left(0.2 \mathrm{M} \mathrm{Na}_{2} \mathrm{~B}_{4} \mathrm{O}_{7}, \mathrm{pH} 8.5\right)$ and resuspended in dilution buffer $(0.5 \%$ Tween 20 and $0.5 \%$ bovine serum albumin in PBS) prior to the addition of antiBrdU mouse antibodies (Becton Dickinson). Goat antimouse antibodies labeled with Alexa-Fluor 488 (1:1000; Invitrogen) were applied as secondary antibodies. DNA was stained with 7-amino-actinomycin D (7AAD; Beckman Coulter). The percentage of BrdU-positive cells was determined by flow cytometry analysis (Beckman Coulter). BrdU incorporation rate (FL1) was plotted versus cellular DNA content (FL3) using Cell Lab Quanta ${ }^{\mathrm{TM}}$ software.

\section{Antioxidant activity}

DPPH assay. The ability of $a$-amyrin to scavenge the diphenyl 1-picrylhydrazyl (DPPH) free radical was quantified as described by Konczak-Islam et al. (2003). Results are expressed as $\mathrm{IC}_{50}$, which is the concentration of the analyte able to scavenge $50 \%$ of the DPPH free radical. Ascorbic acid (Sigma) and $a$-tocopherol (MP Biochemicals, Inc.) were used as positive controls (hydrophilic and hydrophobic, respectively).

FRAP assay. Total antioxidant potential of $\alpha$-amyrin was evaluated using the FRAP assay (ferric reducing antioxidant power), according to the protocol of Benzie and Strain (1996). In this assay ability of a compound to reduce ferric $\left(\mathrm{Fe}^{3+}\right)$ to ferrous $\left(\mathrm{Fe}^{2+}\right)$ ions is estimated, with the use of an indicator dye (2,4,6-tripyridyl- $S$ triazine). Results are expressed as $\mathrm{IC}_{50}$, which is the concentration of the analyte that reduces $50 \%$ of the ferric ions. Ascorbic acid and $a$-tocopherol were used as positive controls

Scavenging of intracellular reactive oxygen species (ROS). Cells were seeded in 24 -well plates at $10^{5}$ cells/ well and let to attach overnight. After 2-hr incubation with $a$-amyrin (final concentration $20 \mu \mathrm{g} / \mathrm{ml}$ ) cells were washed with PBS and loaded with 50 mM carboxy-2',7' dichlorodihydrofluorescein diacetate (c- $\mathrm{H}_{2} \mathrm{DCF}-\mathrm{DA}$; Sig$\mathrm{ma}$ ) dissolved in DMSO (final DMSO conc. $0.5 \% \mathrm{v} / \mathrm{v}$ ) for $30 \mathrm{~min}$. Then cells were washed and ROS generation was induced by exposition to UVA radiation $\left(5 \mathrm{~kJ} / \mathrm{m}^{2}\right.$ for $15 \mathrm{~min}$.). ROS generation was measured indirectly as the fluorescence of oxidized derivative of c- $\mathrm{H}_{2} \mathrm{DCF}(485$ $/ 538 \mathrm{~nm} \mathrm{Ex/Em),} \mathrm{by} \mathrm{a} \mathrm{microplate} \mathrm{reader} \mathrm{(Wallace} \mathrm{Vic-}$ tor 1420) and expressed as a fold increase calculated versus the control (vehicle-treated non-irradiated cells).

\section{Protection against UVB irradiation}

Cells were seeded in 60-mm diameter Petri dishes at the density $10^{5}$ cells/plate (for cyclopyrimidine dimers - CPDs — measurement) or in 24-well plates at $10^{4}$ 
Table 1. Influence of a-amyrin on proliferation of HaCaT cells, measured as changes in total protein content (methylene blue assay), ability to form cell colonies following treatment (clonogenic assay) and to incorporate BrdU (measured by means of flow cytometry, with the use of specific antibodies).

\begin{tabular}{|c|c|c|c|c|c|}
\hline \multirow{2}{*}{$\begin{array}{l}\text { Concentration of } \\
\text { a-amyrin }(\mu \mathrm{g} / \mathrm{ml})\end{array}$} & \multirow{2}{*}{\multicolumn{2}{|c|}{$\begin{array}{l}\text { Total protein content } \\
\text { (\% of control) }\end{array}$}} & \multirow{2}{*}{$\begin{array}{l}\text { Colony forming ability } \\
\text { (\% of control) }\end{array}$} & \multicolumn{2}{|c|}{ BrdU incorporation } \\
\hline & & & & (\% total) & (\% of control) \\
\hline & \multicolumn{5}{|c|}{ Incubation time } \\
\hline & $24 \mathrm{~h}$ & $48 \mathrm{~h}$ & 10 days & $24 \mathrm{~h}$ & \\
\hline 0 & $100 \pm 9.0$ & $100 \pm 6.0$ & $100 \pm 8.6$ & $48.8 \pm 3.2$ & $100.0 \pm 6.6$ \\
\hline 5 & NA & NA & $99.4 \pm 7.0$ & $52.9 \pm 0.8$ & $108.4 \pm 1.6$ \\
\hline 10 & $110.9 \pm 14.3$ & $107.4 \pm 7.9^{*}$ & $110.3 \pm 7.4$ & $56.3 \pm 3.6^{*}$ & $115.3 \pm 7.3^{*}$ \\
\hline 20 & $111.0 \pm 13.8^{*}$ & $116.9 \pm 9.1^{*}$ & $100.1 \pm 5.2$ & $57.8 \pm 1.1^{*}$ & $118.4 \pm 2.2^{*}$ \\
\hline 40 & $104.1 \pm 5.5$ & $117.4 \pm 7.5^{*}$ & NA & NA & \\
\hline
\end{tabular}

Asterisk $\left(^{*}\right)$ indicates a value statistically different from the control $(p<0.05)$; NA, not analyzed

cells/well (for caspase $3 / 7$ activation measurement) and let to attach overnight.

$a$-Amyrin $(20 \mu \mathrm{g} / \mathrm{ml})$ was added to the culture medium $2 \mathrm{~h}$ before the UVB irradiating or (in the case of apoptosis assay) also immediately after treatment. Cells were irradiated with UVB light at an intensity of $10 \mathrm{~mJ} /$ $\mathrm{cm}^{2}$ (for CPDs measurement) or $20 \mathrm{~mJ} / \mathrm{cm}^{2}$ (for caspase $3 / 7$ activation measurement).

CPDs quantification by ELISA. Genomic DNA was isolated either immediately after irradiation or $24 \mathrm{~h}$ later, using Invisorb Spin Cell Mini Kit (Invitek). DNA concentration and purity was estimated spectrophotometrically (NanoDrop ${ }^{\circledR}$ ND-1000). Subsequently CPDs were detected by ELISA with the use of specific antibody, as described elsewhere (Faurschou et al., 2008). Briefly, DNA samples were denaturated at $100^{\circ} \mathrm{C}$ for $10 \mathrm{~min}$ and then rapidly chilled on ice. Denaturated DNA solution $(1 \mu \mathrm{g})$ was transferred into a 96-well plate precoated with $0.003 \%$ protamine sulphate. Plates were incubated in $37^{\circ} \mathrm{C}$ until completely dry, rinsed with distilled water thrice and dried again.

Unspecific antibody-binding sites were blocked with $2 \%$ FCS solution and anti-CPDs antibody was added (MBL International). After washing, the plates were incubated with biotin-F(ab) ${ }^{2}$ fragment of anti-mouse IgG (HpL) (Invitrogen) followed by treatment with peroxidase-streptavidin (Invitrogen) and incubation with the o-phenylene diamine substrate solution. Reaction was stopped by the addition of $2 \mathrm{M} \mathrm{H}_{2} \mathrm{SO}_{4}$. The absorbance was determined at $492 \mathrm{~nm}$ (Wallace Victor 1420).

Quantification of apoptosis. After UVB treatment cells were incubated for $4 \mathrm{hr}$ in the DMEM medium without phenol red (Gibco). UVB-incuded cell death was quantified with the Caspase-Glo 3/7 (Promega Corporation) kit according to manufacture's instructions. Luminescence was measured using a microplate reader (Wallac Victor 1420).

Statistical analysis. All experiments were performed in triplicates. One-way analysis of variance was performed with the use of GraphPad Prism 4 program, and $p<0.05$ value was considered as statistically significant.

\section{RESULTS AND DISCUSSION}

In the present work $a$-amyrin production in $R$. carthamoides plant tissue is documented for the first time. The mass spectrum of the trimethylsilyl derivative showed characteristic ions at $m / z .189$ and 203 in addition to the base peak at $m / z 218$ and a molecular ion at $m / z 498$
(Fig. 1). The amount of $a$-amyrin detected by means of GC-MS analysis was $597.55 \pm 38.2 \mu \mathrm{g} / \mathrm{g}$ dry weight.

The aim of the study was to elucidate if the biological activity of $R$. carthamoides extracts may be attributed to the presence of $a$-amyrin. According to the literature, $a$-amyrin can be considered cytotoxic (Chaturvedula et al., 2004; Chung et al., 2009). However, contrary to expectations, our preliminary investigations indicate its ability to actually stimulate cell proliferation.

Subsequently we investigated the effect of $a$-amyrin on survival and proliferation of eukaryotic cells, as well as its antioxidant potential and ability to protect against cell damage by UVB radiation.

$\mathrm{HaCaT}$ cells, non-tumorigenic, spontaneously immortalized human keratinocytes were used as a model. They are both easy to maintain and closely resemble normal keratinocytes. Even after multiple passages HaCaT cells retain the ability to proliferate and differentiate (Boukamp et al., 1988). These characteristics make them a valuable model for studying the ability of the tested compounds to induce wound-healing processes.

In the first part of our studies, testing the direct $a$-amyrin effect on cell growth, three methods were applied: methylene blue assay (in order to screen for potential $a$-amyrin cytotoxicity), clonogenic assay (to check the long-term effect on cell growth) and BrdU incorporation analyzed by flow cytometry (to estimate cell proliferation rate).

The short-term ( $24 \mathrm{~h}$ and $48 \mathrm{~h}$ ) influence of $a$-amyrin on cell growth and survival was tested with the methylene blue assay. There was no decrease in the cell viabil-

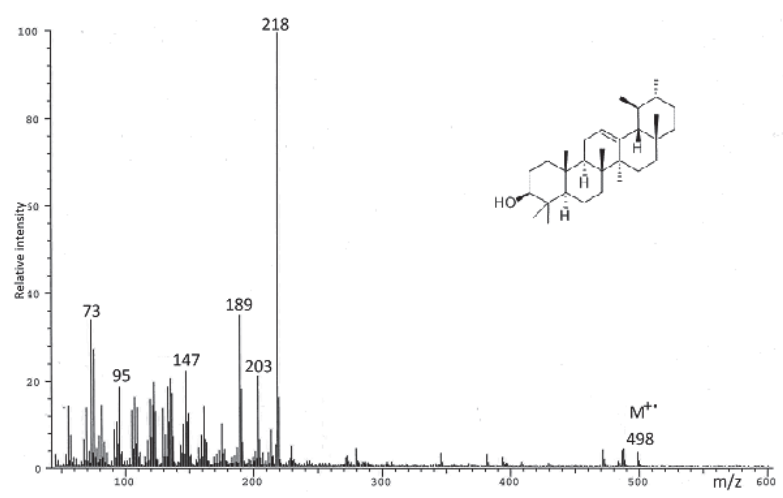

Figure 1. Mass spectrum $(70 \mathrm{eV})$ of trimethylsilyl derivative of a-amyrin $\left(\mathrm{C}_{30} \mathrm{H}_{50} \mathrm{O}\right)$, from $R$. carthamoides leaves. Inset: structure of a-amyrin. 

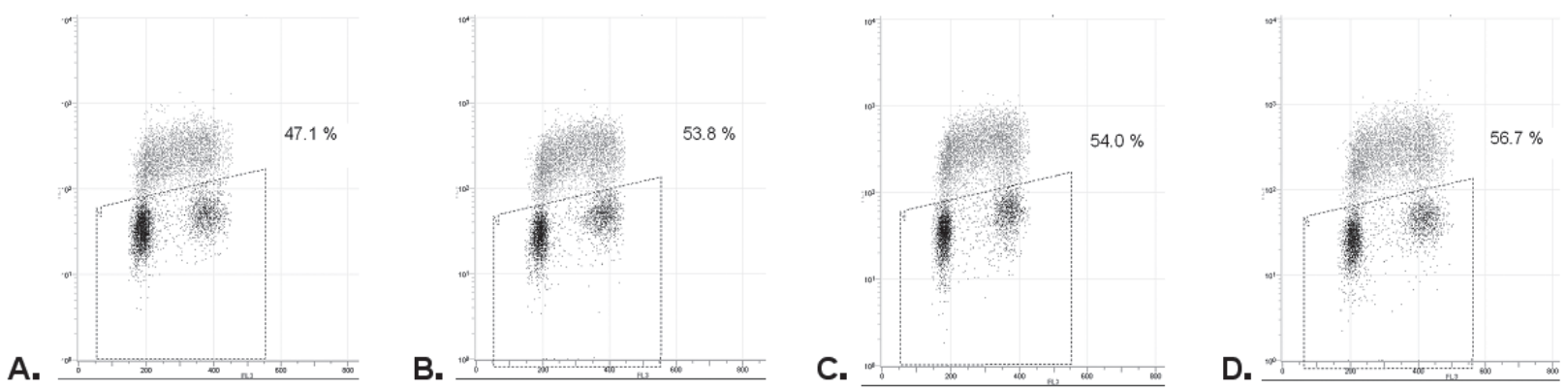

Figure 2. a-Amyrin influence on DNA synthesis measured by BrdU incorporation by $\mathrm{HaCaT}$ cells.

Result of one representative experiment is shown. Percentage of BrdU-positive cells in: (A) vehicle control $(0.8 \% \mathrm{propanol})(\mathbf{B}) 5 \mu \mathrm{g} / \mathrm{ml}$ a-amyrin, (C) $10 \mu \mathrm{g} / \mathrm{ml} \mathrm{a}$-amyrin, (D) $20 \mu \mathrm{g} / \mathrm{ml}$ a-amyrin.

ity within the range of $a$-amyrin concentrations tested; from 10 to $40 \mu \mathrm{g} / \mathrm{ml}$ (Table 1 ). On the contrary, after a 48-h incubation a statistically significant $(p<0.05)$ enhancement of cell growth was observed (Table 1).

The potential toxic/growth inhibitory effect of a longtime (10 days) $a$-amyrin treatment was tested using the clonogenic assay. No perturbations in colony forming were observed over the whole experiment (Table 1).

In order to confirm ability of $a$-amyrin to stimulate cell proliferation, observed previously in the methylene blue assay, the BrdU incorporation rate by HaCaT cells was analyzed by flow cytometry. In accordance with earlier findings $\mathrm{HaCa} \mathrm{T}$ cell growth increase by ca. 15-18\% was observed after $24 \mathrm{~h}$ of incubation with $a$-amyrin (Table 1 and Fig. 2). At the same time no alterations in cell cycle distribution were observed (data not shown).

An ability to stimulate growth of keratinocytes (as well as fibroblasts) by plant-derived components was observed earlier for Phyllanthus muellerianus (Kuntze) Exell aqueous extract and its active constituents, geraiin and furosin. The rate of BrdU incorporation by cells grown in in medium with reduced serum content was almost doubled following geraiin or fucosin treatment, with cell viability being ca. $40 \%$ higher, compared to the control. The same compounds promoted keratinocyte differentiation, upregulating the synthesis of cytokeratins and involucrin (Agyare et al., 2010). Promotion of keratinocytes growth was also caused by a pomegranate seed oil (Aslam et al., 2006) and acidic subfractions of Hibiscus sabdariffa L. polysaccharides (Brunold et al., 2004). The postulated mechanism was activation of membrane-associated growth receptors, eg. KGFR, EGFR InsR (Brunold et al., 2004).

Various terpenoids were also reported to influence cell proliferation. The triterpenoid uvaol (at low doses, ca. $12.5 \mu \mathrm{M}$ ) and maslinic acid (up to $100 \mu \mathrm{M}$ ) increased the proliferation rate of MCF-7 cells by between 20 and $40 \%$. A marked growth stimulation was seen already after $24 \mathrm{~h}$ of incubation (Allouche et al., 2011). Lupeol, isolated from Leptodenia hastate, and its ester derivatives, i.e lupeol hemisuccinate and, to a lower extent, lupeol palmitate and acetate had a stimulatory effect on human epidermis cell proliferation (Nikiéma et al., 2001).

It should be mentioned that $R$. carthamoides extracts exhibit a significant antioxidative potential (Koleckar et al., 2010) and hence the antioxidant activity of the triterpenoid $a$-amyrin was evaluated. Two biochemical assays (DPPH and FRAP) were applied and a cell model, in which the ability of $a$-amyrin to scavenge intracellular ROS induced by UVA irradiation was analyzed. Ascorbic acid, a well-known antioxidant, was used as a positive control. Both those biochemical assays gave negative results, indicating that $a$-amyrin exhibits no direct antioxidant activity (Table 2). This is not surprising, as $a$-amyrin lacks structures mostly related to the antioxidant activity of a compound, such as o-dihydroxybenzene (catechol) structures (present for example in flavonoids; Lu \& Foo, 2001) or 6-hydroxychroman rings (found in tocopherols; Prieto et al., 1999). At the same time the level of intracellular ROS, induced by UVA irradiation, was not decreased following a-amyrin pre-treatment. This observation confirms that $a$-amyrin cannot interact directly with ROS. On the other hand, some compounds not recognized as potent antioxidants (eg. sesquiterpene lactones), are able to alter the cell redox status indirectly by influencing cellular antioxidant mechanisms. The latter may be achieved for example by inducing such pathways as Nrf2/ARE (Umemura et al., 2008) or modifying the activity of antioxidant enzymes like glutathione peroxidase $(\mathrm{GPx})$, glutathione reductase (GR), catalase (CÂT) or su-

Table 2. Antioxidant activity of a-amyrin analyzed with the use of biochemical assays (DPPH and FRAP) and a cell model (scavenging of intracellular ROS induced by UVA irradiation)

\begin{tabular}{|c|c|c|c|}
\hline Method applied & DPPH assay & FRAP assay & Intercellular ROS scavenging \\
\hline Compound analyzed & $\mathrm{IC}_{50}(\mu \mathrm{g} / \mathrm{ml})$ & $\mathrm{IC} \mathrm{C}_{50}(\mu \mathrm{g} / \mathrm{ml})$ & $\begin{array}{l}\text { Fold increase vs. control } \\
\text { (non-irradiated cells) }\end{array}$ \\
\hline a-amyrin & $>150$ & $>150$ & $2.42 \pm 0.18$ \\
\hline ascorbic acid (hydrophilic positive control) & $5.6 \pm 4.7$ & $3.9 \pm 0.5$ & $2.09 \pm 0.15 *$ \\
\hline a-tocopherol (hydrophobic positive control) & $10.8 \pm 3.6$ & $20.9 \pm 2.8$ & NDa \\
\hline $\begin{array}{l}\text { vehicle treated, irradiated cells } \\
\text { (negative control) }\end{array}$ & - & - & $2.38 \pm 0.04$ \\
\hline
\end{tabular}

Asterisk $\left({ }^{*}\right)$ indicates a value significantly different from the control $(p<0.05)$. ${ }^{\text {due }}$ to the low a-tocopherol solubility in cell medium, its ROS scavenging potential was not determined 
peroxide dismutase (SOD) (Jodynis-Lieber et al., 2000). These aspects of $a$-amyrin activity, however, require further examination.

A number of plant compounds, including some terpenoids (eg. certain dicyanoterpenoid derivatives or triterpene saponines), have been found to protect eukaryotic cells against damage caused by UVB radiation (Cai et al., 2008; Dinkova-Kostova et al., 2008). Therefore in the next set of experiments we tried to find out if $a$-amyrin could also exhibit such capacity. First, we assessed the ability of $a$-amyrin to limit the number of cyclo-pyrimidine dimers (CPDs) formed as a consequence of UVB treatment. Secondly, we analyzed apoptosis induction, measured as caspase $3 / 7$ activation resulting from exposing cells to UVB. The obtained data indicate that a-amyrin failed to decrease CPDs formation whether the cells were collected immediately after irradiation (analysis of direct, passive protection, usually attributed to light absorption) or 24 hours later (analysis of indirect involvement in repair mechanisms; data not shown).

Similarily, $a$-amyrin did not prevent apoptosis induced by UVB radiation when cells were pretreated with $a$-amyrin before irradiation or when it was added immediately after UVB treatment. An about four-fold increase of caspase $3 / 7$ activity was observed in cells exposed to UVB versus non-irradiated cells: respectively, 3.65 \pm 0.21 , $3.67 \pm 0.39$ and $3.61 \pm 0.22$ for the vehicle control $(0.8 \%$ isopropanol), cells preincubated for $2 \mathrm{~h}$ with $20 \mu \mathrm{g} / \mathrm{ml}$ $a$-amyrin and cells treated with $20 \mu \mathrm{g} / \mathrm{ml}$ a-amyrin directly after irradiation.

Summarizing, $a$-amyrin induced proliferation rate of human keratinocytes (HaCaT) by up to $18 \%$ and therefore it is an interesting candidate for use in cosmetic industry as an agent promoting wound healing and skin regeneration. However, more detailed analysis should be performed in order to further examine the mechanism of its action and its cellular targets, effect on cell differentiation markers expression, as well as the effect on other cell lines. At the same time it was demonstrated that $a$-amyrin has no apparent antioxidant activity nor does it protect against UVB light.

\section{Acknowledgements}

Financial support was provided by the Ministry of Research and Higher Education, Poland. Projects: DS 8200-4-0085-9 and 3566/B/P01/2007/33.

\section{REFERENCES}

Agyare C, Lechtenberg M, Deters A, Petereit F, Hensel A (2011) Ellagitannins from Phyllanthus muellerianus (Kuntze) Exell.: Geraniin and furosin stimulate cellular activity, differentiation and collagen synthesis of human skin keratinocytes and dermal fibroblasts. Phytomedicine 18: 617-624.

Akihisa T, Kojima N, Kikuchi T, Yasukawa K, Tokuda H, T Masters E, Manosroi A, Manosroi J (2010) Anti-inflammatory and chemopreventive effects of triterpene cinnamates and acetates from shea fat. J Oleo Sci 59: 273-80.

Allouche Y, Warleta F, Campos M, Sánchez-Quesada C, Uceda M, Beltrán G, Gaforio JJ (2011) Antioxidant, antiproliferative, and proapoptotic capacities of pentacyclic triterpenes found in the skin of olives on MCF-7 human breast cancer cells and their effects on DNA damage. J Agric Food Chem 59: 121-130.

Anaya AL, Mata R, Sims JJ, González-Coloma A, Cruz-Ortega R, Guadaño A, Hernández-Bautista BE, Midland SL, Ríos R, Gómez-Pompa A (2003) Allelochemical potential of Callicarpa acuminata. J Chem Ecol 29: 2761-2776.

Aslam MN, Lansky EP, Varani J (2006) Pomegranate as a cosmeceutical source: pomegranate fractions promote proliferation and procollagen synthesis and inhibit matrix metalloproteinase- 1 production in human skin cells. J Ethnopharmacol 103: 311-318.

Babior BM (1984) The respiratory burst of phagocytes. J Clin Invest 73: 599-601.
Barros FW, Bandeira PN, Lima DJ, Meira AS, de Farias SS, Albuquerque MR, Santos HS, Lemos TL, de Morais MO, Costa-Lotufo LV, Pessoa Cdo Ó (2011) Amyrin esters induce cell death by apoptosis in HL-60 leukemia cells. Bioorg Med Chem 19: 1268-1276.

Benzie IF, Strain JJ (1996) The ferric reducing ability of plasma (FRAP) as a measure of "antioxidant power": the FRAP assay. Anal Biochem 239: 70-76.

Biskup E, Szynklarz B, Kumirska J, Golebiowski M, Stepnowski P and Lojkowska E (2007) Comparison of biological activity and composition of extracts from Rhaponticum carbamoides grown on Polish and Siberian plantations. Planta Med 73: 909.

Biskup E, Lojkowska E (2009) Evaluation of biological activities of Rhaponticum carthamoides extracts. J Med Plants Res 3: 1092-1098.

Boukamp P, Petrussevska RT, Breitkreutz D, Hornung J, Markham A, Fusenig NE (1988) Normal keratinization in a spontaneously immortalized aneuploid human keratinocyte cell line. J Cell Biol 106: 761-771.

Brunold C, Deters A, Knoepfel-Sidler F, Hafner J, Müller B, Hensel A (2004) Polysaccharides from Hibiscus sabdariffa flowers stimulate proliferation and differentiation of human keratinocytes. Planta Med 70: $370-373$.

Cai BX, Luo D, Lin XF, Gao J (2008) Compound K suppresses ultraviolet radiation-induced apoptosis by inducing DNA repair in human keratinocytes. Arch Pharm Res 31: 1483-1488.

Chaturvedula VS, Schilling JK, Miller JS, Andriantsiferana R, Rasamison VE, Kingston DG (2004) New cytotoxic terpenoids from the wood of Vepris punctata from the Madagascar Rainforest. $J$ Nat Prod 67: 895-898.

Chobot V, Buchta V, Jahodárová H, Pour M, Opletal L, Jahodár L, Harant P (2003) Antifungal activity of a thiophene polyine from Leurea carthamoides. Fitoterapia 74: 288-290.

Chung IM, Kim MY, Park SD, Park WH, Moon HI (2009) In vitro evaluation of the antiplasmodial activity of Dendropanax morbifera against chloroquine-sensitive strains of Plasmodium falciparum. Phytother Res 23: 1634-1637.

Dinkova-Kostova AT, Jenkins SN, Wehage SL, Huso DL, Benedict AL, Stephenson KK, Fahey JW, Liu H, Liby KT, Honda T, Gribble GW, Sporn MB, Talalay P (2008) A dicyanotriterpenoid induces cytoprotective enzymes and reduces multiplicity of skin tumors in UV-irradiated mice. Biochem Biophys Res Commun 367: 859-865.

Faurschou A, Gniadecki R, Calay D, Wulf HC (2008) TNF-alpha impairs the S-G2/M cell cycle checkpoint and cyclobutane pyrimidine dimer repair in premalignant skin cells: role of the PI3K-Akt pathway. I Invest Dermatol 128: 2069-2077.

Holanda Pinto SA, Pinto LM, Guedes MA, Cunha GM, Chaves MH, Santos FA, Rao VS (2008) Antinoceptive effect of triterpenoid alpha,beta-amyrin in rats on orofacial pain induced by formalin and capsaicin. Phytomedicine 15: 630-634.

Jodynis-Liebert J, Murias M, Błoszyk E (2000) Effect of sesquiterpene lactones on antioxidant enzymes and some drug-metabolizing enzymes in rat liver and kidney. Planta Med 66: 199-205.

Kehrer JP (1993) Free radicals as mediators of tissue injury and disease. Crit Rev Toxicol 23: 21-48.

Koleckar V, Brojerova E, Rehakova Z, Kubikova K, Cervenka F, Kuca K, Jun D, Hronek M, Opletalova V, Opletal L (2010) In vitro antiplatelet activity of flavonoids from Leuzea carthamoides. Drug Chem Toxicol 31: 27-35.

Konczak-Islam I, Yoshimoto M, Hou DX, Terahara N, Yamakawa O (2003) Potential chemopreventive properties of anthocyanin-rich aqueous extracts from in vitro produced tissue of sweetpotato (Ipomoea batatas L.). J Agric Food Chem 51: 5916-5922.

Lee J, Jung E, Lee J, Huh S, Kim J, Park M, So J, Ham Y, Jung K, Hyun CG, Kim YS, Park D (2007) Panax ginseng induces human Type I collagen synthesis through activation of Smad signaling. $J$ Ethnopharmacol 109: 29-34.

Leewenburgh C, Hansen P, Shaish A, Holloszy JO i Heinecke JW (1998) Markers of protein oxidation by hydroxyl radical and reactive nitrogen species in tissues of aging rats. Am J Physiol 274: 453-461.

$\mathrm{Lu} \mathrm{Y,} \mathrm{Foo} \mathrm{Y} \mathrm{(2001)} \mathrm{Antioxidant} \mathrm{activities} \mathrm{of} \mathrm{polyphenols} \mathrm{from} \mathrm{sage}$ (Salvia officinalis). Food Chem 75: 197-202.

Melo CM, Carvalho KM, Neves JC, Morais TC, Rao VS, Santos FA, Brito GA, Chaves MH (2010) Alpha,beta-amyrin, a natural triterpenoid ameliorates L-arginine-induced acute pancreatitis in rats. World J Gastroenterol 16: 4272-4280.

Miliauskas G, van Beek TA, de Waard P, Venskutonis RP, Sudhölter EJ (2005) Identification of radical scavenging compounds in Rhaponticum carthamoides by means of LC-DAD-SPE-NMR. I Nat Prod 68: $168-172$

Müller K i Gürster D (1993) Hydroxyl radical damage to DNA sugar and model membranes induced by anthralin (dithranol). Biochem Pharmacol 46: 1695-1704.

Nikiéma JB, Vanhaelen-Fastré R, Vanhaelen M, Fontaine J, De Graef C, Heenen M (2001) Effects of antiinflammatory triterpenes isolated from Leptadenia hastata latex on keratinocyte proliferation. Phytother Res 15: 131-134. 
Oliveira FA, Chaves MH, Almeida FR, Lima RC Jr, Silva RM, Maia JL, Brito GA,Santos FA, Rao VS (2005) Protective effect of alpha- and beta-amyrin, a triterpene mixture from Protium heptaphyllum (Aubl.) March. trunk wood resin, against acetaminophen-induced liver injury in mice. I Ethnopharmacol 98: 103-108.

Pavlík M, Laudová V, Grüner K, Vokác K, Harmatha J (2002) Highperformance liquid chromatographic analysis and separation of $N$ feruloylserotonin isomers. I Chromatogr B Analyt Technol Biomed Life Sci 770: 291-295.

Prieto P, Pineda M, Aguilar M (1999) Spectrophotometric quantitation of antioxidant capacity through the formation of a phosphomolybdenum complex: specific application to the determination of vitamin E. Anal Biochem 26: 337-341.

Reuter J, Wölfle U, Weckesser S, Schempp C (2010) Which plant for which skin disease? Part 1: Atopic dermatitis, psoriasis, acne, condyloma and herpes simplex. J Dtsch Dermatol Ges 8: 788-796.
Sharaf M, Skiba A, Weglarz Z, El-Ansari MA (2001) Two flavonol 5 -O-glycosides from the roots of Leuzea carthamoides. Fitoterapia 72: 940-942.

Thannical VJ, Fanburg BL (2000) Reactive oxygen species in cell signaling. Am J Physiol-Lung C 279: 1005-1028.

Umemura K, Itoh T, Hamada N, Fujita Y, Akao Y, Nozawa Y, Matsuura N, Iinuma M, Ito M (2008) Preconditioning by sesquiterpene lactone enhances $\mathrm{H}_{2} \mathrm{O}_{2}$-induced $\mathrm{Nrf2} / \mathrm{ARE}$ activation. Biochem Biophys Res Commun 368: 948-954.

Villaseñor IM, Canlas AP, Faustino KM, Plana KG (2004) Evaluation of the bioactivity of triterpene mixture isolated from Carmona retusa (Vahl.) Masam leaves. J Ethnopharmacol 92: 53-56.

Yance D (2004): Rhaponticum carthamoides: Monograph and Review of the Literature. American Herbalists Guide 5: 9-17. 